\title{
The Factors that are Related to Visiting Participants of the Chronic Disease Management Program to the Prolanis Aerobic Club in Lampung Central Regency, 2020
}

\author{
Samsul Maarif' ${ }^{1}$ Bambang \\ Setiaji $^{2}$, Noviansyah ${ }^{3}$, Dian \\ Utama Pratiwi ${ }^{4}$ \\ ${ }^{1}$ Magister Kesehatan \\ Masyarakat, Fakultas Kesehatan, \\ Universitas Mitra Indonesia \\ ${ }^{2}$ Magister Kesehatan \\ Masyarakat, Fakultas \\ Kesehatan, Universitas Mitra \\ Indonesia \\ ${ }^{3}$ Magister Kesehatan \\ Masyarakat, Fakultas \\ Kesehatan, Universitas Mitra \\ Indonesia \\ ${ }^{4}$ Magister Kesehatan \\ Masyarakat, Fakultas \\ Kesehatan, Universitas Mitra \\ Indonesia \\ Email: \\ Arisandiwilliam45@gmail.com
}

Received : March $5^{\text {th }} 2021$

Accepted : May $4^{\text {th }} 2021$

Published : May 20 2021

\begin{abstract}
Over the past two decades, there has been a significant epidemiological transition, non-infectious diseases have become a major burden, even though the burden of non-infectious diseases is still heavy. The number of Prolanis Clubs in Central Lampung is 78, which consists of 39 clubs which are in 39 Community Health Centers and 39 Clubs from Private First Level Health Clinics and Private Practitioners. The number of Prolanis participants in Central Lampung Regency was 3397 participants, with the most in the ArafaH Clinic as many as 396 participants. The purpose of this study is to determine the factors associated with the visit of Chronic Disease Management Program participants to the Prolanis Club in Central Lampung Regency in 2020.

This study uses a cross sectional study design. The study population was all Prolanis participants. A sample of 215 people. Data collection using a questionnaire filled directly by respondents, data analysis using logistic regression tests.

The results showed there was a relationship of knowledge ( $p$ value 0.002 . OR 2.5), attitude ( $\mathrm{p}$ value 0,000 . OR 5.29), perception ( $\mathrm{p}$ value 0,000 . OR 3.8 ), family support ( $\mathrm{p}$ value 0.003 . OR 2,4 ), accessibility (p value 0,000 . OR 3,2) with Prolanis participants 'visit to Prolanis Club in Central Lampung Regency in 2020. Attitude is the most dominant factor related to Prolanis participants' visit to Prolanis Club, which has the highest OR value, namely 11,266. Suggestions for the research are expected that health workers carrying out prolanist activities increase their role as educators by providing education about Type 2 Diabetes Mellitus and Hypertension and emphasizing the importance of participating in prolanist activities so as to increase the positive attitude of prolanist participants towards Prolanist activities.
\end{abstract}

Keywords: Factors, visit, prolanis

Copyright @ 2021 IIK STRADA Indonesia All right reserved.

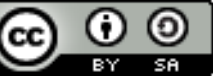

This is an open-acces article distributed under the terms of the Creative Commons Attribution-ShareAlike 4.0 International License. 
The Factors that are Related to Visiting Participants.....

\section{INTRODUCTION}

Based on the results of Basic Health Research (Riskesdas) in 2013 showed the prevalence of Diabetes in Indonesia based on the diagnosis of health doctors by $1.5 \%$ and increased to $2.0 \%$ in 2018 . The prevalence of diabetes based on the diagnosis of health workers in Lampung Province was 0.4 per 1000 population. Meanwhile for Lampung Province the prevalence of DM reached $0.99 \%$ and for Central Lampung District it reached 0.89\% (Riskesdas, 2018).

The 10 biggest diseases in Lampung province, in 2015 primary essential hypertension ranked first with a percentage of $30 \%$, while other hypertension diseases ranked second with a percentage reaching 17\% and for diabetes mellitus reaching 4\% and ranked eighth (Provincial Profile Lampung, 2015).

Whereas for Central Lampung Regency the Hypertension morbidity rate reached $14.9 \%$ and higher than other Regencies such as West Tulang Bawang Regency which is 9.3\%. While based on the 2018 Riskesdas known to the prevalence of hypertension in Central Lampung Regency reached 12.61\%.

The health management strategy initially focused more on curative and rehabilitative. However, now promotive and preventive are the focus of health care. As a way to realize the above, the Health Insurance Provider Board (BPJS) organizes the Chronic Disease Management Program (PROLANIS). PROLANIS is a health service system and a proactive approach implemented in an integrated manner that involves Participants, Health Facilities and Health BPJS in the context of health care for BPJS Health participants who suffer from chronic diseases to achieve optimal quality of life with cost of effective and efficient health services. The aim is to encourage participants with chronic diseases to achieve optimal quality of life with an indicator of $75 \%$ of registered participants visiting First Level Health Facilities having "good" results on specific tests for Type 2 diabetes mellitus and hypertension according to the relevant Clinical Guidelines so as to prevent disease complications. The target is all BPJS Health Participants with chronic diseases (Type 2 Diabetes Mellitus and Hypertension, so that patients who have diabetes have no complications (BPJS, 2014). Activities in Prolanis include medical / educational consultation activities, Home Visit, Reminder, club activities and monitoring the health status With the entry into force of the National Health Insurance since January 2014, in accordance with the mandate of Law No. 40 of 2004 concerning the National Social Security System and Law Number 24 of 2011 concerning BPJS, the first level health facilities of Community Health Centers (Puskesmas) as the frontline in providing services to the community, can implement the Prolanis program, in collaboration with BPJS to provide guidance for patients with chronic diseases.

The number of Prolanis Clubs in Central Lampung is 78, which consists of 39 clubs which are in 39 Community Health Centers and 39 Clubs from Private First Level Health Clinics and Private Practitioners. The number of Prolanis participants in Central Lampung Regency was 3397 participants, with the most in the Arafat Clinic as many as 396 participants. Based on pre-survey data, some participants said that they came to the prolanis club to get medicine and seek treatment with a Puskesmas doctor. The interview results show that those who do not understand the benefits of the Prolanis club.

\section{MATERIALS AND METHODS}

This research is a quantitative research with an analytic approach. The study was conducted in February 2020 at the Sukanegara Health Center, Simpang Agung Health Center and Arafah Clinic in Central Lampung Regency. This study uses an analytic survey design with cross sectional approach. The study of population was all Prolanis participants at the Sukanegara Health Center as the Puskesmas with 
the least Prolanis participants (16 participants), Simpang Agung Health Center as a Puskesmas with a moderate number of Prolanis participants (51 participants) and the Arafat Clinic as the First Level Health Facility with the most Prolanis participants many (396 participants) in Central Lampung District in December 2019 with a total population of 463 people. A sample of 215 respondents. Independent variables in this study are knowledge, and attitudes, family support, accessibility and perception. The dependent variable in this study was the visit of Prolanist participants to the Prolanist Club. Data collection was carried out using a questionnaire compiled by the researcher himself.

\section{RESULTS}

\section{Univariate Analysis}

Table 1 .

The distribution of Frequency of Knowledge, and Attitudes, Family Support, Accessibility, Perceptions and Visits of Prolanist Participants to Prolanis Clubs in Central Lampung Regency in 2020

\begin{tabular}{|c|c|c|}
\hline Variable & Total & $\%$ \\
\hline \multicolumn{3}{|l|}{ Knowledge } \\
\hline - Good & 97 & 45.1 \\
\hline - $\mathrm{Bad}$ & 118 & 54.9 \\
\hline \multicolumn{3}{|l|}{ Attitude } \\
\hline - Positive & 100 & 46.5 \\
\hline - Negative & 115 & 53.5 \\
\hline \multicolumn{3}{|l|}{ Perception } \\
\hline - Positive & 119 & 55.3 \\
\hline - Negative & 96 & 44.7 \\
\hline \multicolumn{3}{|l|}{ Family Support } \\
\hline - Support & 108 & 50.2 \\
\hline - does not support & 107 & 49.8 \\
\hline \multicolumn{3}{|l|}{ Accessibility } \\
\hline - Near & 99 & 46.0 \\
\hline- Far & 116 & 54.0 \\
\hline \multicolumn{3}{|l|}{ Participant Visit } \\
\hline - Active & 91 & 42.3 \\
\hline - Passive & 124 & 57.7 \\
\hline Total & 215 & 100.0 \\
\hline
\end{tabular}

Based on Table 1, it is known that of the 215 respondents studied, most of them have poor knowledge, namely 118 respondents (54.9\%), negative attitudes 115 respondents $(53.5 \%)$, positive perception 119 respondents $(55.3 \%)$, family supports 108 respondents $(50.2 \%)$, remote accessibility 116 respondents $(54.0 \%)$ and participants who are not active in Prolanis activities are 124 respondents $(57.7 \%)$. 


\section{Bivariate Analysis}

Table 2.

The relationship of Knowledge, and Attitudes, Family Support, Accessibility, Perception between Prolanis Participants Visit to Prolanis Clubs in Central Lampung District in 2020

\begin{tabular}{|c|c|c|c|c|c|c|c|c|}
\hline & \multicolumn{6}{|c|}{ Prolanis Participants Visit to the Prolanis Club } & \multirow{3}{*}{$\begin{array}{c}P \\
\text { value }\end{array}$} & \multirow[t]{3}{*}{ OR } \\
\hline & \multicolumn{2}{|c|}{ Active } & \multicolumn{2}{|c|}{ Passive } & \multicolumn{2}{|c|}{ Total } & & \\
\hline & $\mathrm{n}$ & $\%$ & $\mathrm{n}$ & $\%$ & $\mathrm{n}$ & $\%$ & & \\
\hline \multicolumn{9}{|l|}{ Knowledge: } \\
\hline Good & 53 & 54.6 & 44 & 45.4 & 97 & 100.0 & \multirow[t]{2}{*}{0,002} & 2,5 \\
\hline Bad & 38 & 32.2 & 80 & 67.8 & 118 & 100.0 & & $(1,4-4,4)$ \\
\hline \multicolumn{9}{|l|}{ Attitude: } \\
\hline Positive & 63 & 63.0 & 37 & 37.0 & 100 & 100.0 & \multirow[t]{2}{*}{0,000} & 5,29 \\
\hline Negative & 28 & 24.3 & 87 & 75.7 & 115 & 100.0 & & $(2,9-9,5)$ \\
\hline \multicolumn{9}{|l|}{ Perception: } \\
\hline Positive & 67 & 56.3 & 52 & 43.7 & 119 & 100.0 & \multirow[t]{2}{*}{0,000} & 3,8 \\
\hline Negative & 24 & 25.0 & 72 & 75.0 & 96 & 100.0 & & $(2,1-6,9)$ \\
\hline \multicolumn{9}{|l|}{ Family Support: } \\
\hline Support & 57 & 52.8 & 51 & 47.2 & 108 & 100.0 & \multirow[t]{2}{*}{0,003} & 2,4 \\
\hline does not support & 34 & 31.8 & 73 & 68.2 & 107 & 100.0 & & $(1,4-4,2)$ \\
\hline \multicolumn{9}{|l|}{ Accessibility: } \\
\hline Near & 57 & 57.6 & 42 & 42.4 & 99 & 100.0 & \multirow[t]{2}{*}{0,000} & 3,2 \\
\hline Far & 34 & 29.3 & 82 & 70.7 & 116 & 100.0 & & $(1,9-5,8)$ \\
\hline Total & 91 & 42.3 & 124 & 57.7 & 215 & 100.0 & & \\
\hline
\end{tabular}

Based on the above table, it is known that there is a relationship of knowledge with the visit of Prolanis participants to the Prolanis Club in Central Lampung Regency in 2020 (p value 0.002. OR 2.5). There is an attitude relationship with the visit of Prolanis participants to the Prolanis Club in Central Lampung Regency in 2020 ( $p$ value 0,000. OR 5.29). There is a perception relationship with the visit of Prolanis participants to the Prolanis Club in Central Lampung Regency in 2020 (p value 0,000. OR 3.8). There is a relationship of family support with the visit of Prolanis participants to the Prolanis Club in Lampung Tengah District in 2020 ( $\mathrm{p}$ value 0.003 . OR 2.4). There is an accessibility relationship with the visit of Prolanis participants to the Prolanis Club in Lampung Tengah Regency in 2020 (p value 0,000. OR 3.2).

\section{Multivariate Analysis}

Table 3.

Multivariate Analysis Results

\begin{tabular}{lcccc}
\hline \multicolumn{1}{c}{ Variable } & OR & p value & \multicolumn{2}{c}{$95.0 \%$ C.I } \\
\cline { 4 - 5 } & & & Lower & Upper \\
\hline Knowledge & 5,570 &, 000 & 2,524 & 12,289 \\
Attitude & 11,266 &, 000 & 4,939 & 25,697 \\
Perception & 9,212 &, 000 & 3,870 & 21,930 \\
Family Support & 6,380 &, 000 & 2,757 & 14,767 \\
Accessibility & 5,472 &, 000 & 2,522 & 11,875 \\
Constant &, 011 &, 000 & & \\
\hline
\end{tabular}




\section{DISSCUSSION}

\section{Relationship of Knowledge with Prolanist Participants Visiting the Prolanist Club}

The statistical test results obtained $\mathrm{p}$ value of 0.002 , it can be concluded that there is a relationship of knowledge with the visit of Prolanis participants to Prolanis Club in Central Lampung District in 2020. The analysis results also obtained an OR value of 2.5, which means that wellinformed respondents have 2.4 times the chance great to be active in visits to the Prolanis Club compared to the not well-informed.

Rogers in the book of Notoatmodjo (2012) states that change or adoption of behavior through several stages of a very sequential process. Efforts to provide knowledge and awareness of the importance of these are the main factors in the stages of the process. The awareness and knowledge will then build interest and effort to try the desired behavior.

In line with Ahmalia research (2018) which shows the relationship of knowledge with adherence to the Chronic Disease Management Program, p value $=0.008<\alpha 0.05$ means that there is a significant relationship between knowledge and adherence to the Chronic Disease Management Program.

The results of this study are also the same as the research conducted by Qorry (2015). In his research on the factors related to the compliance of hypertension sufferers following Prolanis in the Kedungmundu Community Health Center of Semarang City also found a relationship between knowledge and patient compliance.

The picture obtained shows that there is a relationship between the level of knowledge acquired / owned by the respondent and his actions in participating in prolanis activities.

From the experience and research, it is proven that behavior based on knowledge will be more lasting than behavior that is not based on knowledge. Rongers research cited by Notoatmojo (2012) revealed that before people adopt new behaviors in a person, sequential processes occur such as awareness, interest, evaluating and applying the knowledge they have. In line with the research, it was also found that active participation of sufferers in the form of adherence to Prolanis activities was apparently influenced by the understanding of the respondents, understanding here was from knowing about the dangers of hypertension and diabetes complications to being able to apply their knowledge well. To convey information, the number of respondents with low education was also alleged to be one of the causes of the lack of absorption of the information provided, so that their knowledge of the Prolanis program was also lacking, this resulted in a lack of patient awareness in controlling their illness.

According to researchers, the behavior of Prolanis participants' visits to the Prolanis Club has something to do with the knowledge of Prolanis Club participants. Where according to Notoatmodjo (2007) there are 3 factors that influence a person to behave, one of which is a predisposing factor, namely knowledge. Many people are wrong in choosing the method of treatment and utilization of health facilities, because they do not know about what is a disease, how it came and how to prevent it and where to look for healing efforts. Therefore, lack of knowledge or ignorance about it is clearly a predisposition rather than the behavior that leads to the occurrence of the disease.

Whereas in this study, there are results that show that despite having good knowledge (30 respondents) but rarely come or attend a visit to the prolanis club or there is also even though the knowledge is not good ( 8 respondents) but still active in the prolanis club. This, according to the researcher, is caused by a reinforcing factor, which requires support from outside the personal 
respondent who can change the behavior. Where supporting factors or support from the family is very important to be able to encourage respondents to come or not come to the prolanis club. It could also be due to support from health workers, where in the Prolanis club in Central Lampung Regency, it is required to provide a telephone number to the officer so that before each implementation of the prolanis, the officer gives a message via sms to remind participants to be able to attend the prolanis club. Likewise, every month counseling is conducted on various matters relating to the illnesses suffered by the participants so that it encourages participants to always be curious to come to the Prolanis Club.

It is recommended to Puskesmas in Central Lampung Regency, to always be able to maintain the consistency of the programs that have been run at the prolanis club, so that the participants will continue to grow. In addition, the authors suggest that, to increase the knowledge of prolanis participants both about the prolanis itself and knowledge about health, it would be nice if at a certain time to bring in internal medicine specialists to increase knowledge about health, or can also bring the BPJS so as to explain as widely as possible about the Prolanis club, as well as adjusting the methods and media of counseling to the condition of the participants who are mostly elderly who have a decline in cognitive abilities.

\section{Relationship between Attitude and Prolanist Participant Visit to the Prolanist Club}

The statistical test results obtained $\mathrm{p}$ value of 0,000 , it can be concluded that there is a relationship between attitude and the visit of Prolanis participants to Prolanis Club in Central Lampung Regency in 2020. The analysis results also obtained an OR value of 5.29, which means that respondents were positively 5.29 times more likely great to be active in visits to the Prolanis Club compared to those who are negative.

The Attitude is a person's feelings about objects, activities, events and other people. This feeling becomes a concept that represents someone likes or dislikes (positive, negative, or neutral) on something. The Attitudes emerge from various forms of assessment. Attitudes are developed in three models, namely affection, behavioral tendencies, and cognition. Affective responses are physiological responses that express an individual's preference for something. Behavioral tendencies are verbal indications of an individual's intentions. Cognitive response is a cognitive evaluation of an attitude object. Most individual attitudes are the result of social learning from their environment (Wales, 2009).

According to the researchers, in this study there was a significant relationship to the number of visits to the prolanis due to several things that are closely related to the attitude that has three components which together form a whole attitude (total attitude) and are influenced by knowledge, thoughts, beliefs and emotions. The attitude is not necessarily automatically manifested in an action, required supporting factors or a condition that allows the realization of an action, including the factor of facilities and factors of support from other parties. These factors are thought to influence attitudes and behavior.

\section{Relationship of Perception with Prolanist Participants Visiting the Prolanist Club}

The statistical test results obtained $p$ value of 0,000 , it can be concluded that there is a perception relationship with the visit of Prolanis participants to Prolanis Club in Central Lampung Regency in 2020. The analysis results also obtained an OR value of 3.8 which means that respondents with 
positive perceptions 3.8 times more likely great to be active in visits to the Prolanis Club compared to those who have negative perceptions.

Patients who participate in prolanis activities are good enough, their knowledge continues to increase by attending health education activities every month in line with research Rasajati and colleagues (2015) states that there is a relationship between the level of knowledge about the management of hypertension with medication adherence. Purnamasari (2017) states there is a relationship between the level of knowledge and perception with the compliance of prolanis participants in undergoing treatment at the Puskesmas.

\section{Relationship of family support with the visit of Prolanist participants to the Prolanist Club}

The statistical test results obtained $p$ value 0.003 , it can be concluded that there is a relationship of family support with the visit of Prolanis participants to Prolanis Club in Central Lampung Regency in 2020. The analysis results also obtained an OR value of 2.4 , which means that respondents with families support the opportunity 2.4 times are more likely to be active in visits to the Prolanis Club compared to those without family support.

Safarino (2006) explains that the emotional support received is a message for individuals that the individual is loved. The comfort and serenity arising from emotional support will help individuals to cope with the various emotional reactions they feel. The family functions as a collector and disseminator of information. Good advice, suggestions, instructions and information will make someone obedient to that advice, including in providing information about the schedule and benefits of participating in Prolanis activities.

The family as a safe and peaceful place to rest and learn and assist in mastery of emotions, including maintaining emotional relationships include support that is manifested in the form of empathy, caring, trust, attention and listening or listening to the person concerned. The existence of an inner bond between the respondent and family members fosters affection, meaning that family members want the health of the respondent to be known when participating in Prolanis Club activities.

The family is the closest person to the sufferer who can control their health condition. But in this case the role of families in efforts to prevent complications of hypertension and diabetes by following the Prolanis program on their families was still lacking. According to the researchers' assumptions, this condition certainly can aggravate the disease experienced by sufferers, due to lack of supervision of themselves and also preventive measures against the illness suffered.

The family is a group that has a very important role in developing, preventing, adapting and or fixing health problems found in the family. To achieve healthy behavior in the community, it must be started in each family structure. The family is a conducive place for healthy behavior to grow for children as potential members of the community, so promotion plays an important role (Notoadmojo, 2010).

This is in line with Tawakal's (2015) research in factors related to the utilization of chronic disease management programs (Prolanis). There is a significant relationship between family support for the utilization of chronic disease management programs. According to Green in Notoadmodjo (2012) attitudes and behaviors of others is a reinforcing factor for someone to utilize health services in this case is the attitude and behavior of the family. Support from families in this case is advice and 
suggestions for utilizing chronic disease management programs. Family support also proves by the willingness of family members to accompany and take the respondent to the Prolanis site.

The support from family in this case can be in the form of advice to use prolanis. The willingness of family members to accompany and escort respondents is also a proof of family support. Family members are also considered to have an influence on a person's behavior in utilizing health services, because one's behavior is also obtained and influenced from the family environment. Family support is important in influencing one's health. The more family support that is given, the greater the chance and desire for someone to be healthy.

According to researchers, the high level of family support for Prolanis activities is due to the high awareness of the community in making preventive efforts from diseases, so they realize that it is better to prevent than to treat by controlling health conditions while exercising. Therefore it would be nice if the form of family support not only supports family members coming to the prolanis club, but supervising at home to these family members to maintain their health at home by maintaining a healthy lifestyle.

Prolanis participants who are mostly elderly have some limitations, especially those who suffer from degenerative diseases, thus requiring family support to make a visit to Prolanis, this is constrained because the activities carried out by Prolanis conflict with the daily schedule of family members such as work schedules, so they cannot take Participants participating in Prolanis activities, it would be better if Prolanis activities outside working hours, so the family can help Participants to attend Prolanis activities.

\section{Relationship of Accessibility with Prolanist Participants Visiting the Prolanist Club}

The statistical test results obtained $p$ value of 0,000 , it can be concluded that there is a relationship of accessibility with the visit of Prolanis participants to Prolanis Club in Central Lampung Regency in 2020. The analysis results also obtained an OR value of 3.2, which means that respondents with close accessibility have the opportunity 3.2 times greater to be active in visits to the Prolanis Club compared to remote accessibility.

Utilization of health services at the health center level has several factors that influence it, namely consumer factors in the form of: education, livelihoods, knowledge and perceptions of patients; Organizational factors include: availability of resources, affordability of service locations, and social access; and service provider factors including: health worker behavior (Dever, 2014).

Transportation is very important in supporting community access to health services. Ideally, community outreach to health care facilities should be as easy as possible so that people can obtain the health services they want (Hapsari, 2013).

\section{Multivariate}

Based on the results of multivariate analysis, it is known that the attitude variable which most influences the dependent variable (activeness) with sig $=\rho=0.046$ is said to be influential because the value of $\rho<0.05$. Where from the value of $\operatorname{Exp}(\mathrm{B})$ or OR (Odds Ratio) it can be concluded that Prolanis participants have an opportunity of 11,266 times to increase activity in Prolanis activities. If the respondent's attitude is good then the possibility of the respondent will be active in participating in Prolanis activities, so as to increase the activity in Prolanis activities at the Prolanis Club in Central Lampung Regency. 
Research conducted by Saleem and colleagues, (2012), states that patient attitudes have a role in maintaining patient compliance with anti-hypertensive medications at the beginning or during treatment. The negative attitude of respondents is indicated by the attitude of respondents who suffer from Diabetes Mellitus with adherence to follow the dietary recommendations that have been determined by health workers (Phitri, 2013). The positive attitude of the patient towards prevention efforts so that Type 2 Diabetes Mellitus and Hypertension will accept and apply the way to prevent the disease, while the negative attitude of the patient will tend to reject the prevention efforts. Attitude is an internal ability of patients who are very instrumental in taking action, open attitude shown can be seen from the actions of sufferers of Diabetes Mellitus and Hypertension following prolanis activities.

This is in line with the negative attitude shown by informants with DM and hypertension who refuse to participate in prolanis activities. The following are the results of the interview:

"what do I do? I don't have the chance to take part in this gathering. because at home no one takes care of it so if I take part in activities from the morning the house doesn't clean, nobody cooks." (TN, 54 years old).

"what should I do, the gathering place is far from home, so sorry, why is it like wasting time, when the activities are explained the same as what was explained when checking. "(YT, 52 years).

The people with diabetes and hypertension can't participate in prolanis activities because there is a lot of work to be done in the morning such as going to the garden, washing, cleaning and cooking, there are also reasons that no one takes care of their stalls because their children go to school and her husband goes to the garden or go to sea, distance between the house and the puskesmas.

The informant's positive attitude can be seen from agreeing to join prolanis to find out health conditions such as what is our blood pressure and how to prevent hypertension. Like the following interview excerpt:

"There are no disadvantages to participating in this activity, there are so many benefits so you know the symptoms, how to take medicine given the medicine with a doctor. then the body feels light because of participating in aerobic activities. " (EM, 54 years old).

"Agree with this activity, many benefits are right, can know abstinence from my illness, how to manage my eating ways. and can also check blood pressure regularly. I also know the complication if it is not regular, namely stroke which can make paralyzed, I don't want to bother my family, so I join this activity. " (MH, 51 years old).

We recommend that you routinely participate in prolanis activities every week so that DM and hypertension do not recur because DM and hypertension are very dangerous which can cause a person to have a stroke and disability if not prevented from now.

This shows a negative attitude will cause a sufferer to not obediently follow medication or prolanis activities. Patient's attitude has a role in maintaining compliance, unfavorable beliefs in 
sufferers will also lead to unfavorable attitudes resulting in non-compliance. People with diabetes mellitus and hypertension who have negative attitudes are unable to take preventative and treatment measures. Patients with type 2 diabetes mellitus and hypertension who have a positive attitude have gone through an education process towards maturity with various components such as being able to control emotions, being able to distinguish good and bad and so on. This means that the patient has all or maybe some of these components, for example the patient is able to distinguish that the treatment of hypertension or diabetes mellitus will take a long time so it needs patience to take medication routines and sports activities or patience to face the desire for food that we like but is prohibited because it includes dietary restrictions.

So, researchers suggest that health workers at the prolanis club always involve a lot of support from other parties for the benefit of the club, especially family support. Where family support is a major factor in the attendance of club participants to prolanis clubs. If the family does not support, then the presence of diminishing returns. In addition, support from community leaders and across sectors is an important factor as well. It would be nice if involved outside parties for matters relating to the welfare of club participants or it could also be moral support for prolanis club participants in Central Lampung Regency.

\section{CONCLUSION}

1. The frequency distribution of respondents who have bad knowledge, 118 respondents (54.9\%), negative attitudes 115 respondents (53.5\%), positive perception 119 respondents (55.3\%), families support 108 respondents $(50.2 \%)$, accessibility 116 respondents (54.0\%) and 124 inactive participants in Prolanis activities $(57.7 \%)$

2. There is a relationship of knowledge with the visit of Prolanis participants to the Prolanis Club in Central Lampung Regency in 2020 ( $p$ value 0.002. OR 2.5).

3. There is an attitude relationship with the visit of Prolanis participants to the Prolanis Club in Central Lampung Regency in 2020 ( $p$ value 0,000. OR 5.29).

4. There is a perception relationship with the visit of Prolanis participants to the Prolanis Club in Central Lampung Regency in 2020 ( $p$ value 0,000. OR 3.8).

5. There is a relationship of family support with the visit of Prolanis participants to the Prolanis Club in Lampung Tengah District in 2020 ( $p$ value 0.003. OR 2.4).

6. There is an accessibility relationship with the visit of Prolanis participants to the Prolanis Club in Lampung Tengah District in 2020 ( $p$ value 0,000. OR 3.2).

7. Attitude is the most dominant factor related to the visit of Prolanis participants to the Prolanis Club, which has the highest OR score of 11.266.

\section{REFERENCES}

Abdulah (2017) Faktor Penyebab Terjadinya Penurunan Jumlah Kunjungan Peserta Program Pengelolaan Penyakit Kronis (Prolanis) Di Puskesmas Minasa Upa Kota Makassar

Aghoja, O. C., Okinedo, P. O., \& Odili, V. U. (2017). Knowledge, Attitude and Practice of Hypertensive Patients towards Hypertension in a Secondary Health Care Facility in Delta State. UK Journal of Pharmaceutical and Biosciences, 5(2), 24-33.

Anggraini, D., Zulpahiyana, Z., \& Mulyanti, M. (2015). Faktor Dominan Lansia Aktif Mengikuti Kegiatan Posyandu di Dusun Ngentak. Jurnal Ners dan Kebidanan Indonesia, 3(3), 150-155. 
The Factors that are Related to Visiting Participants.....

Arikunto, S. 2012. Prosedur Penelitian Suatu Pendekatan Praktik. Jakarta: Rineka Cipta

Azwar, 2013. Sikap Manusia Teori dan Pengukurannya. Yogyakarta, Pustaka Pelajar.

Balitbang Kemenkes RI. 2013. Riset Kesehatan Dasar; RISKESDAS. Jakarta: Balitbang Kemenkes RI

Bovet, P., Gervasoni, J. P., Mkamba, M., Balampama, M., Lengeler, C., \& Paccaud, F. (2008). Low utilization of health care services following screening for hypertension in Dar es Salaam (Tanzania): a prospective population-based study. BMC Public Health, 8(1), 407.

BPJS. panduan praktis PROLANIS (Program Pengelolaan Penyakit Kronis)

Departemen Promosi Kesehatan. 2010. Pedoman Pengelolaan Penyakit Kronis. Jakarta: PT. Askes (Persero)

Green, Lawrence. 2005. Health Education Planning A Diagnostic Approach. Baltimore. The John Hopkins University, Mayfield Publishing Co,

Harniati, A., Suriah, S., \& Amqam, H. (2019). Ketidakpatuhan Peserta Bpjs Kesehatan Mengikuti Kegiatan Prolanis Di Puskesmasrangas Kabupaten Mamuju. Jurnal Keasyarakat Maritim, 1(1).

Kassahun, C. W., \& Mekonen, A. G. (2017). Knowledge, attitude, practices and their associated factors towards diabetes mellitus among non-diabetes community members of Bale Zone administrative towns, South East Ethiopia. A cross-sectional study. PloS one, 12(2).

Kuncoro, 2002. Dukungan Sosial Keluarga Bagi Ibu Hamil. Bandung: Rajawali Press

Manihuruk, Melita, and Mardiati Nadjib. "Faktor-faktor yang Berhubungan dengan Kunjungan Lansia ke Posbindu Lansia di Wilayah Kerja Puskesmas Kelurahan Bintara Kota Bekasi Tahun 2017." Jurnal Kebijakan Kesehatan Indonesia: JKKI 7.4 (2018): 158-167.

Notoatmodjo, S. 2010. Metodologi Penelitian Kesehatan. Jakarta: Rineka Cipta

Notoatmodjo,S, 2010, Promosi Kesehatan Teori dan Aplikasi, Jakarta, Rineka Cipta

Purnamasari, V. D. (2017). Pengetahuan Dan Persepsi Peserta Prolanis Dalam Menjalani Pengobatan Di Puskesmas. PREVENTIA, 2(1).

Rahmi (2015) Faktor-faktor yang Berhubungan dengan Pemanfaatan Program Pengelolaan Penyakit Kronis (PROLANIS) di BPJS Kesehatan Kantor Cabang Jakarta Timur tahun 2015

Siddique, M. K. B., Islam, S. M. S., Banik, P. C., \& Rawal, L. B. (2017). Diabetes knowledge and utilization of healthcare services among patients with type 2 diabetes mellitus in Dhaka, Bangladesh. BMC health services research, 17(1), 586.

Soegondo S. Diagnosis dan Kalsifikasi Diabetes Mellitus Terkini. Dalam Soegondo S dkk (eds), Penatalaksanaan Diabetes Mellitus Terpadu. Penerbit FKUI. Jakarta. 2013

Sugiyono. 2012. Metode Penelitian Kombinsasi. Bandung: Alfabeta

Tawakal, Ismaniar. (2015). Faktor-faktor yang berhubungan dengan pemanfaatan program pengelolaan penyakit kronis (Prolanis di BPJS Kesehatan Kantor Cabang Tangerang tahun 2015

Tsou, M. T. (2018). Healthcare Service Utilization and Associated Factors in Community-Dwelling Elderly in Northern Taiwan: One Medical Center's Experience. International Journal of Gerontology, 12(2), 144-149

Yuliaristi (2018) Faktor-Faktor yang Mempengaruhi Pemanfaatan Prolanis di Wilayah Kerja Puskesmas Mandala Kecamatan Medan Tembung Tahun 2018 